\title{
Mass Media and Corporate Communication Media: Access and Usage in Karnataka
}

\author{
Jesus Milton Rousseau S., Manavik P. Raj
}

\begin{abstract}
The technological advancements and communication revolution has resulted in the majority of people across the developed and developing nations accessing information through mass media. Organisations use corporate communication to project a positive image in the eyes of its stakeholders. The success of any organization depends on its corporate communication strategies. Corporate communication professionals use diverse tools and approaches via corporate communication media to achieve the goals and objectives of their organisation. The purpose of the study was to find out which mass media is extensively used; different types of corporate communication media accessed and which corporate communication media is extensively used by the people in Karnataka. Also, a comparison was made among the selected districts in Karnataka to understand which district is better exposed to mass media and corporate communication media. The data were collected from 600 respondents across Karnataka from 4 districts namely - Bengaluru, Mysuru, Kalaburagi and Dharwad. The study found that among the mass media, the newspaper was more prominent and among the various corporate communication media, corporate information from social media was more extensively used. The district wise analysis showed that Mysuru district was better exposed to mass media and Kalaburagi was better exposed to corporate communication media in Karnataka.
\end{abstract}

Keywords: Corporate communication, Karnataka, Bengaluru, Mysuru, Kalaburagi, Dharwad, mass media, corporate communication media, oral media, internal media, corporate website, corporate advertisements, corporate events and exhibits, corporate annual reports, social media.

Author: Dr. Jesus Milton Rousseau S., Communications Consultant, e-mail: jesusmilton@gmail.com, Dr. Manavik P. Raj ${ }^{2}$ Communications Consultant \& Visiting faculty, Bengaluru e-mail: manavikraj@gmail.com

\section{Introduction}

Mass communication usually refers to the process of disseminating any kind of information by an individual or a group of people to a large number (mass) of people or heterogeneous audience by means of a channel or communication or mechanical device (medium). The channel of communication can be print, TV, radio, internet etc. Today, mass communication is popular with mass media like television, radio, cinema and print media. With the advancements in technology and the communication revolution, majority of the people across developed and developing nations access some form of mass media like radio, television, newspapers, internet and mobile telephony. People across different geographies access and prefer different types of mass media. Information, education, opinion, entertainment and a number of contemporary ideas are usually transmitted to an invisible audience spread across a geographical area by mass media.

e-ISSN - 2581-334X

JMSD, April - June 2018 
Corporate communication is defined by Joseph Fernandez as, "Corporate communications is a long-term strategic initiative taken by a corporate organization to communicate the core brand and its core messages to a spectrum of audiences in a globalised market environment. At its core, corporate communication is very simple, the way a corporate communicates." (Fernandez, 2004) Corporate communication professionals use a variety of corporate communication media to achieve the goals and objectives of their company. The success of a company depends on their corporate communication strategies.

The international influence of corporate communication could be seen in our country as well. Private multinational companies, Indian owned companies and even public-sector undertakings or government enterprises have recognized the importance of corporate communication. Lately, the old public relations departments have been transformed into modern corporate communication departments to achieve the company's corporate goals. Corporate communication professionals have specific roles in building relations with various target groups.

The prime goal of corporate communication is building, enhancing, preserving and reinforcing the image of the organisation or company in the eyes and minds of the internal and external publics. The internal stakeholders of the company include employees and other workers, external stakeholders include policymakers, opinion leaders, competitors, professional bodies, special interest groups, media, customers (industrial, wholesalers, dealers, consumers) and the public at large. The internal and external stakeholders are reached through mass media and the following corporate communication media: Oral media, internal media, corporate websites, corporate annual reports, corporate advertising, corporate events and exhibits and corporate information on social media. (Riel, 2007)

Corporate communication media is the medium used by corporate organisations to disseminate information to all its stakeholders. The different types of corporate communication media used by corporate communication professionals are: Oral media like management speeches and interviews help in communicating the objectives of the company to its stakeholders. Internal media like printed literature - brochures, leaflets and house journals play an important role while the company intends to disseminate specific information on the group's viewpoint to a specific audience - special features, prices, etc. Corporate websites play a positive role as corporate communication tools by providing information and creating a unique identity in the web space about the company i.e. services offered, products catalogue, advertisements, career information, history of the company, etc. Corporate annual reports are reports which summarise the major activities of the company in the preceding year. The main goal of corporate annual reports is to give information to shareholders and stakeholders, about the company's activities and financial performance. Corporate advertising, unlike product advertising, promotes the company's name, image, personnel, and reputation of the company and helps in building the brand image. Corporate events and exhibits are used to display the product portfolios of the companies to its stakeholders in exhibitions and trade fairs. Corporate information on social media is the information about the company being posted and usually gets instantaneous feedback. Indian corporate communication practitioners in general and Karnataka, in particular, are also employing these corporate communication tools, though not in all. Certain variations could be noticed in the application of these media keeping in view the specific needs of the organisational goals and target audiences. 


\section{Purpose}

Many studies have focused on the media habits or media usage patterns of mass media, social media, or specific channels of mass media like newspaper, radio, television, advertising etc. PR specialists traditionally concentrated on the in-house media and community media to project the identity of their organisation. Most of the studies in the discipline of Public Relations within mass communication and media have attempted to explain the efficacy and advantages of PR media tools. The present study is the first of its kind to compare mass media and corporate communication media on its access and usage patterns in Karnataka.

The purpose of this study is to find out which mass media is extensively used; different types of corporate communication media accessed by the people in Karnataka; which corporate communication media is extensively used. Also, a comparison among the 4 selected districts in Karnataka will enable us to understand which district is better exposed to mass media and corporate communication media in Karnataka.

\section{Literature Review}

Earlier research studies have analysed mass media habits in the context of the media industry. Press in the developing countries have established that communication plays a major role in the dimension of development. It surely points out that there is a correlation between the means of development and mass media usage. (Sommerlad, 1966) It has also been established that there exists a link to better media exposure and the development process, in most of the developing countries of the world. (Schramm, 1964) Also, Wilbur Schramm recognized that information is a crucial factor in the development process.

A recent study on media usage survey revealed that "the media usage of students and instructors include a mixture of traditional and new media." (Capretz et al, 2015) Another study highlighted patterns of mass media use among the aged and found "daily newspaper readership is about as common among the aged as among the rest of the population and nearly all of the elderly watch television for several hours a day and therefore have this second channel of news and entertainment to keep in touch with the world." (Wright, 1988) Further, a study examined family media habits, including the use of television, movies, videos, computer and video games, the internet, music, and print media. The findings were organized into areas of media habits and attitudes, the connection between media habits and school performance, and the connection between media habits and media effects. The study concluded that "wise use of media can help develop knowledge and skills, as well as provide engaging entertainment; unwise use can be harmful." (Gentile, 1999) A study on patterns of media usage among European citizens found following user groups: 1) Non-users, 2) Average users, 3) Instrumental users, 4) Entertainment users and 5) Advanced users. (Heim \& Brandtzaeg, 2007)

A report by the Newspaper Association of America Foundation as part of its longstanding emphasis on young newspaper readers reviewed three significant studies and found that "Media consume the lives of teens. Teens are not just doing one thing when they consume media. They split their enormous media time among many activities - social networking, viewing video, exchanging Instant Messages, viewing graphics and photos, listening to music, watching TV, playing games, looking up things, even catching up on the news - often simultaneously. Likewise, they divide their media usage among many platforms: cell phones, MP3 players, gaming devices, television, computers and printed materials. They use different devices for 
different purposes in different places." (Vahlberg, 2010)

There are not many significant studies on the corporate communication media habits and usage patterns. Megha Trivedi's doctoral study on competitive advantage through corporate communication found a significant effect of corporate communication on the corporate image of the organization. The study also confirmed that "corporate communication is important for the corporate image of an organization irrespective of the industry." (Trivedi, 2014)

Mahesh Chandra Guru's study on corporate communication in public and private corporate houses of Karnataka state, has analyzed the corporate communication system, process and practices among corporate communication professionals in select public and private sector undertakings, namely - BEML, BHEL, Mphasis and Biocon. The study found a "surge in corporate communication interest which is typically attributed to the strong relationship between corporate communication and business management." (Guru \& Raghavendra, 2013)

However, the above research studies have not compared specifically mass media usage and corporate communication media usage among the general public or the target groups. Therefore, the present study tries to fill this gap in view of the corporate communications discipline.

\section{Research Questions}

RQ1: Which mass media was extensively used by the people in Karnataka?

RQ2: What are the different types of corporate communication media accessed in Karnataka?

RQ3: Which corporate communication media was extensively used by the people in Karnataka?

RQ4: Which district in Karnataka is better exposed to mass media?

RQ5: Which district in Karnataka is better exposed to corporate communication media?

\section{Methodology}

In the present study, relevant information was collected from people across Karnataka, in 4 districts namely - Bengaluru, Mysuru, Kalaburagi and Dharwad by using survey method. The stratified random sampling method was used to select the samples for the survey. The survey is a popular method used in social science research, as it is the most cost-effective and relevant research method.

A questionnaire was developed and used to collect data as an instrument of survey method. The data were collected from 600 respondents through a questionnaire prepared for a major research project. The relevant data were collected from 150 respondents across each of the 4 selected districts in Karnataka namely - Bengaluru, Mysuru, Kalaburagi and Dharwad. A percentage analysis was tabulated and used to deduce the major findings and inferences.

\section{Analysis and Discussion}

\subsection{Demographic profile}

A total of 150 respondents were randomly selected from each of the chosen 4 districts in Karnataka, namely, Bengaluru, Dharwad, Kalaburagi and Mysuru, summing to 600 respondents. Gender wise, the majority of the respondents i.e. 59.8\% were males and females were $40.2 \%$ respectively. Across age group, the sample revealed that $37.0 \%$ of the respondents were in the age group of $29-39$ years, $36.8 \%$ of them were in the age group of $18-28$ years, $22.5 \%$ of them 
were in the age group of 40-50 years and remaining 3.7\% of them were in the age group above 51 years. $73.8 \%$ of the respondents were in the age group of 18-39 years. The educational qualification profile of the sample reveals, $43.7 \%$ of the respondents were postgraduates, $32.8 \%$ were graduates, $13.2 \%$ were PUC and $10.3 \%$ were others with degrees like diplomas, PGDBM, etc. Hence, all the respondents were literate in this study. Occupation wise, $32.2 \%$ worked in the private sector, $21.2 \%$ were in employed government service, $10.8 \%$ worked in the agriculture sector, around $16.7 \%$ were self-employed, another $16.7 \%$ worked in other sectors and $7.5 \%$ worked in the public sector. Hence, the majority of the respondents in the sample worked in private sector companies. Monthly income wise, $71 \%$ of the respondents earned less than Rs. 30,000 per month, $19.3 \%$ earned between Rs. 30,001 and Rs. 60,000 and 9.7\% of them earned above Rs. 60,001 per month.

\subsection{Mass Media access and usage}

Mass media is the most commonly accessed media by the common man across gender, age, geography, race etc. The role of mass media is very crucial in any developing society, the present study has attempted to specifically understand the media access and usage pattern of the respondents under study, as a whole, in Karnataka and various districts, namely, Bengaluru, Dharwad, Kalaburagi and Mysuru. Data was gathered and analysed for the mainstream mass media - Newspapers, Magazine, Radio, Television, Internet and Mobile telephony. The mass media analysis was done as part of a major study undertaken on image building and development of Karnataka state. The study has revealed several interesting facts.

Table 1: Mass Media exposure: access and time spent

\begin{tabular}{|c|c|c|c|c|c|c|c|c|c|}
\hline \multirow{2}{*}{$\begin{array}{l}\text { Mass } \\
\text { media }\end{array}$} & & & & \multicolumn{4}{|c|}{ District } & \multirow[t]{2}{*}{ Total } & \multirow{2}{*}{$\begin{array}{c}\text { Test } \\
\text { statistics }\end{array}$} \\
\hline & & & & Bengaluru & Dharwad & Kalaburagi & Mysuru & & \\
\hline \multirow[t]{10}{*}{ Newspaper } & \multirow{10}{*}{$\begin{array}{l}\text { Time } \\
\text { spent }\end{array}$} & Yes & $\mathrm{F}$ & 148 & 143 & 145 & 146 & 582 & $\mathrm{CV}=.070$ \\
\hline & & & $\%$ & $98.70 \%$ & $95.30 \%$ & $96.70 \%$ & $97.30 \%$ & $97.00 \%$ & $\mathrm{P}=.395$ \\
\hline & & $<1 \mathrm{hr}$ & $\mathrm{F}$ & 94 & 118 & 90 & 118 & 420 & $\mathrm{CV}=.144$ \\
\hline & & & $\%$ & $63.50 \%$ & $82.50 \%$ & $62.10 \%$ & $80.80 \%$ & $72.20 \%$ & $\mathrm{P}=.000$ \\
\hline & & $1-2 \mathrm{hr}$ & $\mathrm{F}$ & 45 & 25 & 50 & 23 & 143 & \\
\hline & & & $\%$ & $30.40 \%$ & $17.50 \%$ & $34.50 \%$ & $15.80 \%$ & $24.60 \%$ & \\
\hline & & $2-3 \mathrm{hr}$ & $\mathrm{F}$ & 8 & 0 & 2 & 3 & 13 & \\
\hline & & & $\%$ & $5.40 \%$ & $0.00 \%$ & $1.40 \%$ & $2.10 \%$ & $2.20 \%$ & \\
\hline & & $3 \mathrm{hr}+$ & $\mathrm{F}$ & 1 & 0 & 3 & 2 & 6 & \\
\hline & & & $\%$ & $0.70 \%$ & $0.00 \%$ & $2.10 \%$ & $1.40 \%$ & $1.00 \%$ & \\
\hline \multirow[t]{10}{*}{ Magazines } & \multirow{10}{*}{$\begin{array}{l}\text { Time } \\
\text { spent }\end{array}$} & Yes & $\mathrm{F}$ & 112 & 84 & 107 & 117 & 420 & $\mathrm{CV}=.184$ \\
\hline & & & $\%$ & $74.70 \%$ & $56.00 \%$ & $71.30 \%$ & $78.00 \%$ & $70.00 \%$ & $\mathrm{P}=.000$ \\
\hline & & $<1 \mathrm{hr}$ & $\mathrm{F}$ & 78 & 55 & 53 & 87 & 273 & $\mathrm{CV}=.154$ \\
\hline & & & $\%$ & $69.60 \%$ & $65.50 \%$ & $49.50 \%$ & $74.40 \%$ & $65.00 \%$ & $\mathrm{P}=.000$ \\
\hline & & $1-2 \mathrm{hr}$ & $\mathrm{F}$ & 26 & 29 & 50 & 25 & 130 & \\
\hline & & & $\%$ & $23.20 \%$ & $34.50 \%$ & $46.70 \%$ & $21.40 \%$ & $31.00 \%$ & \\
\hline & & $2-3 \mathrm{hr}$ & $\mathrm{F}$ & 5 & 0 & 4 & 2 & 11 & \\
\hline & & & $\%$ & $4.50 \%$ & $0.00 \%$ & $3.70 \%$ & $1.70 \%$ & $2.60 \%$ & \\
\hline & & $3 \mathrm{hr}+$ & $\mathrm{F}$ & 3 & 0 & 0 & 3 & 6 & \\
\hline & & & $\%$ & $2.70 \%$ & $0.00 \%$ & $0.00 \%$ & $2.60 \%$ & $1.40 \%$ & \\
\hline \multirow[t]{4}{*}{ Radio } & \multirow{4}{*}{$\begin{array}{l}\text { Time } \\
\text { spent }\end{array}$} & Yes & $\mathrm{F}$ & 105 & 131 & 134 & 110 & 480 & $\mathrm{CV}=.211$ \\
\hline & & & $\%$ & $70.00 \%$ & $87.30 \%$ & $89.30 \%$ & $73.30 \%$ & $80.00 \%$ & $\mathrm{P}=.000$ \\
\hline & & $<1 \mathrm{hr}$ & $\mathrm{F}$ & 72 & 58 & 41 & 83 & 254 & $\mathrm{CV}=.310$ \\
\hline & & & $\%$ & $68.60 \%$ & $44.30 \%$ & $30.60 \%$ & $75.50 \%$ & $52.90 \%$ & $\mathrm{P}=.000$ \\
\hline
\end{tabular}




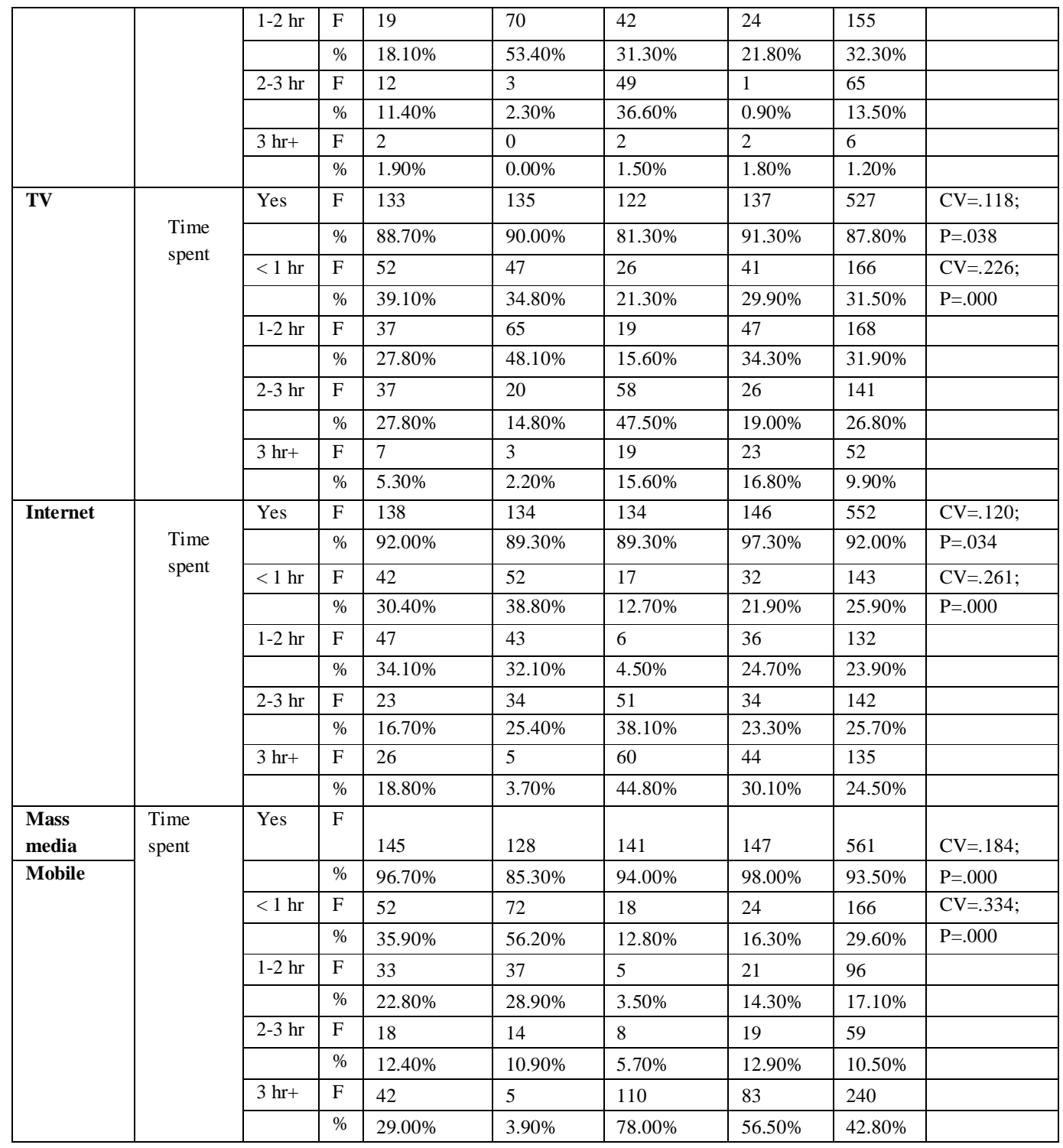

On the whole, the majority of the respondents i.e. $97.0 \%$ of them read the newspaper. While analysing the time spent on reading the newspaper every day, it was found that $72.2 \%$ of the respondents spent less than 1 hour, $24.6 \%$ of them spent $1-2$ hours, $2.2 \%$ of them spent $2-3$ hours and remaining $1 \%$ of them spent more than 3 hours reading newspapers. Also, it was found that respondents from Bengaluru (98.7\%) spent more time reading newspapers and Dharwad $(95.3 \%)$ respondents spent the least time reading newspapers. (See Table 1)

The study found that more than $70 \%$ of the respondents read magazines. While analysing the time spent on reading magazines, it was found that $65 \%$ of the respondents spent less than 1 hour, $31 \%$ of them spent $1-2$ hours, $2.6 \%$ of them spent $2-3$ hours and remaining $1.4 \%$ of them spent more than 3 hours reading magazines. Also, it was found that respondents from Mysuru (78\%) spent more time reading magazines and Dharwad (56\%) respondents spent the least time reading magazines. (See Table 1 )

The audio medium radio had more than $80 \%$ listenership among the respondents. While analysing the time spent on listening to the radio, it was found that $52.9 \%$ of the respondents spent less than 1 hour, $32.3 \%$ of them spent $1-2$ hours, $13.5 \%$ of them spent $2-3$ hours and 
remaining $1.2 \%$ of them spent more than 3 hours listening to the radio. Also, it was found that respondents from Kalaburagi $(89.3 \%$ ) spent more time listening to the radio and Bengaluru (70\%) respondents spent the least time listening to the radio. (See Table 1)

The audio-visual medium Television had around $87.8 \%$ of the respondents, watching it regularly. While analysing the time spent on watching television, it was found that $31.5 \%$ of the respondents spent less than 1 hour, $31.9 \%$ of them spent $1-2$ hours, $26.8 \%$ of them spent 2-3 hours and remaining $9.9 \%$ of them spent more than 3 hours watching television. Also, it was found that respondents from Mysuru (91.3\%) spent more time watching television and Kalaburagi (81.3\%) respondents spent the least time viewing television. (See Table 1)

The new media or online medium Internet had around $92 \%$ of the respondents accessing it every day. While analysing the time spent on accessing the internet, it was found that $25.9 \%$ of the respondents spent less than 1 hour, $23.9 \%$ of them spent 1-2 hours, $25.7 \%$ of them spent 2-3 hours and remaining $24.5 \%$ of them spent more than 3 hours accessing the internet. Also, it was found that respondents from Mysuru (97.3\%) spent more time accessing the internet and Dharwad \& Kalaburagi both had $89.3 \%$ of the respondents spending least time accessing the internet. (See Table 1)

The study found that more than $93.5 \%$ of the respondents used mobile phones to access information. While analysing the time spent on mobile usage, it was found that $29.6 \%$ of the respondents spent less than 1 hour, $17.1 \%$ of them spent $1-2$ hours, $10.5 \%$ of them spent $2-3$ hours and remaining $42.8 \%$ of them spent more than 3 hours per day using mobile. Also, it was found that respondents from Mysuru (98\%) spent more time on mobile usage and Dharwad $(85.3 \%)$ respondents spent the least time on mobile usage.

Among the mass media, the newspaper was more prominent with $97 \%$ of the respondents reading it every day, followed by mobile with $93.5 \%$ and Internet with $92 \%$. The least accessed media was the magazine with $70 \%$ of the respondents reading it. It can be deduced that in Karnataka, still print media or newspaper are among the preferred mass media, even in the rural districts.

The present study has revealed that a large percentage of respondents are exposed to mass media including mobile telephony. Over $97 \%$ of the respondents read newspapers. Magazines are read by only $70 \%$ of the respondents. Over $80 \%$ of the respondents listen to Radio and Television is viewed by around $87.8 \%$. Around $92 \%$ of the respondents were also digitally literate and used the Internet as an important source of information. Mobile telephony is very popular in Karnataka and over $93.5 \%$ of the respondents use mobile phones.

District wise analysis (average of percentages) of mass media showed that $89.2 \%$ of the respondents from Mysuru district are better exposed and used mass media in Karnataka, compared to other districts with Kalaburagi-87\%, Bengaluru $-86.8 \%$ and Dharwad $-83.9 \%$.

Bengaluru and Mysuru districts have an edge in the newspaper readership, magazine readership, Television viewership, internet usage and mobile usage. Dharwad and Kalaburagi districts have better radio listenership. Mysuru district respondents spend more time reading newspapers (1.4\% of respondents read more than 3 hours per day) Readers in Bengaluru spent more time reading newspapers 2-3 hours with 5.4\%, while $30.4 \%$ spend $1-2$ hours and $63.5 \%$ of the respondents spend at least 1 hour. Magazine readership is found to be more in Mysuru district and they $(74.4 \%)$ also spend more time reading magazines, at least for 1 hour. While Kalaburagi respondents (46.7\%) read at least 1-2 hours. For Radio, respondents from Kalaburagi listen to 
radio more than other districts and $21.8 \%$ of the respondents listen to radio $1-2$ hours, while $75 \%$ of them spend 1 hour. Listeners in Dharwad spend more time $53.45 \%$ listening to Radio between 1-2 hours, while in Bengaluru 11.4\% of the respondents spend time listening to Radio.

Television viewership in Karnataka takes the fourth position in terms of popularity as revealed in the present study. Viewers in Mysore (91.3\%) and Dharwad (90\%) spend more time watching television compared to Kalaburagi (81.3\%) and Bengaluru (88.7\%) districts. $16.8 \%$ of the viewers from Mysuru watch Television for more than 3 hours and $47.5 \%$ of the viewers watch Television between 2-3 hours in Kalaburagi and about $48.1 \%$ of the viewers watch TV between 1-2 hours. And $39.1 \%$ of the viewers watch Television less than 1 hour. Internet usage is higher in Mysuru and Bengaluru districts. Respondents in Dharwad district spend less than 1 hour, followed by Bengaluru district $34.1 \%$ of the respondents use internet between 1-2 hours whereas in Kalaburagi district $38.1 \%$ spend 2-3 hours on the Internet. Again, more than $44.8 \%$ of the respondents use internet for more than 3 hours. Among the mass media, mobile telephony is the second most popular mass media in Karnataka. Mysuru district respondents (98\%) use mobile telephony, followed by Bengaluru district $96.7 \%$. About $56.2 \%$ of the respondents in Dharwad district use less than 1 hour followed by Bengaluru district 34.9\%. In Dharwad district respondents (28.9\%) spend between 1-2 hours on their mobiles, followed by Bengaluru district (22.8\%). Mysuru respondents use mobile about 12.9\%, between 2-3 hours, followed by Bengaluru (12.4\%). Surprisingly, respondents from Kalaburagi (78\%) district use the mobile phone for more than 3 hours in a day, followed by Mysuru $(56.5 \%)$ district.

The district-wise comparison revealed no significant association $(\mathrm{CV}=.070 ; \mathrm{p}=.395)$ between the respondents of various districts exposure to and reading newspapers. Cramer's V revealed a significant association $(\mathrm{CV}=.144 ; \mathrm{p}=.000)$ between time spent and districts. Districtwise comparison of exposure to and reading of magazines revealed a significant association $(\mathrm{CV}=.184 ; \mathrm{p}=.000)$ between the respondents of various districts reading magazines. Cramer's $\mathrm{V}$ revealed a significant association $(\mathrm{CV}=.154 ; \mathrm{p}=.000)$ between time spent on the reading of magazines and in different districts. The district-wise comparison revealed a significant association $(\mathrm{CV}=.211 ; \mathrm{p}=.000)$ between the respondents of various districts listening to programmes on radio. Further, Cramer's V revealed a significant association $(\mathrm{CV}=.310 ; \mathrm{p}=.000)$ between time spent on listening to radio and districts. The district-wise comparison revealed a significant association $(\mathrm{CV}=.118 ; \mathrm{p}=.038)$, between the respondents of various districts watching television. Further, Cramer's V revealed a significant association $(\mathrm{CV}=.226 ; \mathrm{p}=.000)$ between time spent on watching television and districts. The district-wise comparison revealed a significant association $(\mathrm{CV}=.120 ; \mathrm{p}=.034)$ between the respondents of various districts accessing the internet. Further, Cramer's V revealed a significant association $(C V=.261 ; p=.000)$ between time spent on Internet and districts. The district-wise comparison revealed a significant association $(\mathrm{CV}=.184 ; \mathrm{p}=.000)$ between the respondents of various districts using mobile telephony. Further, Cramer's V revealed a significant association $(\mathrm{CV}=.334 ; \mathrm{p}=.000)$ between time spent on using mobile telephone and districts. (See Table 1)

It was also found that mobile usage is an important instrument of communication and had a significant association $(\mathrm{CV}=.334, \mathrm{p}=.000)$ between the respondents of various districts and access to mobile usage in terms of time spent. Similarly, magazines were also found to have a significant association between the readership and time spent in the usage with $C V=.154$ with a $\mathrm{p}$-value of .000 compared to Radio $(\mathrm{CV}=.211, \mathrm{p}=.000)$. Also, it is observed that Television 
viewing and time spent for viewing were found to be significant in terms of the association between respondents' access and time spent across all parameters and in all the districts for access $(\mathrm{CV}=.118, \mathrm{p}=.038)$ and for usage $(\mathrm{CV}=.226, \mathrm{p}=.000)$. Lastly, all the perceptions of the respondents towards media exposure along with time spent by the respondents were statistically significant at 0.05 . (See Table 1)

\subsection{Corporate communication Media access and usage pattern}

Corporate communication media is the medium used by companies to disseminate important and relevant corporate information on the organisation or the company to all its stakeholders. The present study analysed the role and extent of corporate communication media and its exposure. The study analysed the following corporate communication media: Oral media: management speeches, internal media: house journals, printed literature, corporate websites, corporate annual reports, corporate advertising, corporate events and exhibits and corporate information on social media.

Almost $67.5 \%$ of the respondents listened to oral media like management speeches etc. While analysing the time spent on oral media, it was found that $72.1 \%$ of the respondents spent less than 1 hour, $23.7 \%$ of them spent $1-2$ hours, $3 \%$ of them spent $2-3$ hours and remaining $1.2 \%$ of them spent more than 3 hours listening to management speeches etc. Also, the study found that $91.3 \%$ of the respondents from Kalaburagi spent more time listening to oral media and $48 \%$ of the respondents in Mysuru district spent the least time listening to oral media. (See Table 2)

Majority of the respondents $(60 \%)$ read internal media like in-house journals, printed literature, etc. While analysing the time spent on reading internal media like in-house journals, printed literature, etc. it was found that $55 \%$ of the respondents spent less than 1 hour, $33.6 \%$ of them spent $1-2$ hours, $7.8 \%$ of them spent $2-3$ hours and remaining $3.6 \%$ of them spent more than 3 hours reading internal media like in-house journals, printed literature, etc. Also, the study found that $92 \%$ of the respondents from Kalaburagi spent more time reading internal media like inhouse journals, printed literature, etc. and in Dharwad, $29.3 \%$ of the respondents spent the least time reading it. (See Table 2)

The study found that more than $66.5 \%$ of the respondents visited corporate websites. While analysing the time spent on visiting corporate websites it was found that $66.7 \%$ of the respondents spent less than 1 hour, $21.1 \%$ of them spent 1-2 hours, $8 \%$ of them spent 2-3 hours and remaining $4.3 \%$ of them spent more than 3 hours visiting corporate websites. Also, it was found that $88.7 \%$ of the respondents from Kalaburagi spent more time visiting corporate websites and in Bengaluru, $50 \%$ of the respondents spent the least time visiting corporate websites. (See Table 2)

About $51.7 \%$ of the respondents read corporate annual reports. While analysing the time spent on reading corporate annual reports it was found that $56.5 \%$ of the respondents spent less than 1 hour, $15.2 \%$ of them spent $1-2$ hours, $18.7 \%$ of them spent $2-3$ hours and remaining $9.7 \%$ of them spent more than 3 hours visiting corporate websites. Also, it was found that $85.3 \%$ of the respondents from Kalaburagi spent more time reading corporate annual reports and in Dharwad, $18 \%$ of the respondents spent minimal time reading corporate annual reports. (See Table 2)

Majority of the respondents $(63.2 \%)$ viewed corporate advertisements. While analysing the time spent on viewing corporate advertisements it was found that $58.8 \%$ of the respondents spent less than 1 hour, $20.1 \%$ of them spent $1-2$ hours, $8.2 \%$ of them spent $2-3$ hours and 
remaining $12.9 \%$ of them spent more than 3 hours viewing corporate advertisements. Also, it was found that $82.7 \%$ of the respondents from Mysuru spent more time viewing corporate advertisements and in Dharwad, $46.7 \%$ of the respondents spent the least time viewing corporate advertisements. (See Table 2)

Table 2: Corporate communication Media exposure: access and time spent

\begin{tabular}{|c|c|c|c|c|c|c|c|c|c|}
\hline \multirow{2}{*}{\multicolumn{2}{|c|}{$\begin{array}{c}\text { Corporate } \\
\text { communication } \\
\text { media }\end{array}$}} & \multirow{4}{*}{$\begin{array}{l} \\
\text { Yes }\end{array}$} & & \multicolumn{4}{|c|}{ District } & \multirow{3}{*}{$\begin{array}{r}\text { Total } \\
\\
405\end{array}$} & \multirow{3}{*}{$\begin{array}{c}\text { Test } \\
\text { statistics } \\
\mathrm{CV}=.382 ;\end{array}$} \\
\hline & & & & \multirow{2}{*}{$\begin{array}{r}\text { Bengaluru } \\
79\end{array}$} & \multirow{2}{*}{$\begin{array}{r}\text { Dharwad } \\
117\end{array}$} & \multirow{2}{*}{$\begin{array}{r}\text { Kalaburagi } \\
137\end{array}$} & \multirow{2}{*}{$\begin{array}{r}\text { Mysuru } \\
72\end{array}$} & & \\
\hline Oral & & & $\mathrm{F}$ & & & & & & \\
\hline media & & & $\%$ & $52.70 \%$ & $78.00 \%$ & $91.30 \%$ & $48.00 \%$ & $67.50 \%$ & $\mathrm{P}=.000$ \\
\hline & Time & $<1$ & F & 70 & 111 & 47 & 64 & 292 & $\mathrm{CV}=.356$ \\
\hline & spent & $\mathrm{hr}$ & $\%$ & $88.60 \%$ & $94.90 \%$ & $34.30 \%$ & $88.90 \%$ & $72.10 \%$ & $\mathrm{P}=.000$ \\
\hline & & $1-2$ & $\mathrm{~F}$ & 7 & 4 & 79 & 6 & 96 & \\
\hline & & $\mathrm{hr}$ & $\%$ & $8.90 \%$ & $3.40 \%$ & $57.70 \%$ & $8.30 \%$ & $23.70 \%$ & \\
\hline & & $2-3$ & $\mathrm{~F}$ & 2 & 2 & 8 & 0 & 12 & \\
\hline & & $\mathrm{hr}$ & $\%$ & $2.50 \%$ & $1.70 \%$ & $5.80 \%$ & $0.00 \%$ & $3.00 \%$ & \\
\hline & & 3 & $\mathrm{~F}$ & 0 & 0 & 3 & 2 & 5 & \\
\hline & & hr+ & $\%$ & $0.00 \%$ & $0.00 \%$ & $2.20 \%$ & $2.80 \%$ & $1.20 \%$ & \\
\hline \multirow{10}{*}{$\begin{array}{c}\text { Internal } \\
\text { media }\end{array}$} & & Yes & $\mathrm{F}$ & 83 & 44 & 138 & 95 & 360 & $C V=.456$ \\
\hline & & & $\%$ & $55.30 \%$ & $29.30 \%$ & $92.00 \%$ & $63.30 \%$ & $60.00 \%$ & $\mathrm{P}=.000$ \\
\hline & Time & $<1$ & $\mathrm{~F}$ & 58 & 27 & 37 & 76 & 198 & $\mathrm{CV}=.274$ \\
\hline & spent & $\mathrm{hr}$ & $\%$ & $69.90 \%$ & $61.40 \%$ & $26.80 \%$ & $80.00 \%$ & $55.00 \%$ & $\mathrm{P}=.000$ \\
\hline & & $1-2$ & $\mathrm{~F}$ & 21 & 14 & 71 & 15 & 121 & \\
\hline & & $\mathrm{hr}$ & $\%$ & $25.30 \%$ & $31.80 \%$ & $51.40 \%$ & $15.80 \%$ & $33.60 \%$ & \\
\hline & & $2-3$ & $\mathrm{~F}$ & 2 & 3 & 21 & 2 & 28 & \\
\hline & & $\mathrm{hr}$ & $\%$ & $2.40 \%$ & $6.80 \%$ & $15.20 \%$ & $2.10 \%$ & $7.80 \%$ & \\
\hline & & 3 & $\mathrm{~F}$ & 2 & 0 & 9 & 2 & 13 & \\
\hline & & $\mathrm{hr}+$ & $\%$ & $2.40 \%$ & $0.00 \%$ & $6.50 \%$ & $2.10 \%$ & $3.60 \%$ & \\
\hline \multirow{10}{*}{$\begin{array}{c}\text { Corporate } \\
\text { website }\end{array}$} & & Yes & $\mathrm{F}$ & 75 & 81 & 133 & 110 & 399 & $\mathrm{CV}=.211$ \\
\hline & & & $\%$ & $50.00 \%$ & $54.00 \%$ & $88.70 \%$ & $73.30 \%$ & $66.50 \%$ & $\mathrm{P}=.000$ \\
\hline & Time & $<1$ & $\mathrm{~F}$ & 53 & 49 & 75 & 89 & 266 & $\mathrm{CV}=.257$ \\
\hline & spent & $\mathrm{hr}$ & $\%$ & $70.70 \%$ & $60.50 \%$ & $56.40 \%$ & $80.90 \%$ & $66.70 \%$ & $\mathrm{P}=.000$ \\
\hline & & $1-2$ & $\mathrm{~F}$ & 19 & 30 & 17 & 18 & 84 & \\
\hline & & $\mathrm{hr}$ & $\%$ & $25.30 \%$ & $37.00 \%$ & $12.80 \%$ & $16.40 \%$ & $21.10 \%$ & \\
\hline & & $2-3$ & $\mathrm{~F}$ & 3 & 2 & 26 & 1 & 32 & \\
\hline & & $\mathrm{hr}$ & $\%$ & $4.00 \%$ & $2.50 \%$ & $19.50 \%$ & $0.90 \%$ & $8.00 \%$ & \\
\hline & & 3 & $\mathrm{~F}$ & 0 & 0 & 15 & 2 & 17 & \\
\hline & & hr+ & $\%$ & $0.00 \%$ & $0.00 \%$ & $11.30 \%$ & $1.80 \%$ & $4.30 \%$ & \\
\hline \multirow{10}{*}{$\begin{array}{l}\text { Corporate } \\
\text { annual } \\
\text { reports }\end{array}$} & & Yes & $\mathrm{F}$ & 66 & 27 & 128 & 89 & 310 & $\mathrm{CV}=.489$ \\
\hline & & & $\%$ & $44.00 \%$ & $18.00 \%$ & $85.30 \%$ & $59.30 \%$ & $51.70 \%$ & $\mathrm{P}=.000$ \\
\hline & Time & $<1$ & $\mathrm{~F}$ & 49 & 17 & 39 & 70 & 175 & $\mathrm{CV}=.355$ \\
\hline & spent & $\mathrm{hr}$ & $\%$ & $74.20 \%$ & $63.00 \%$ & $30.50 \%$ & $78.70 \%$ & $56.50 \%$ & $\mathrm{P}=.000$ \\
\hline & & $1-2$ & $\mathrm{~F}$ & 14 & 7 & 11 & 15 & 47 & \\
\hline & & $\mathrm{hr}$ & $\%$ & $21.20 \%$ & $25.90 \%$ & $8.60 \%$ & $16.90 \%$ & $15.20 \%$ & \\
\hline & & $2-3$ & $\mathrm{~F}$ & 2 & 3 & 50 & 3 & 58 & \\
\hline & & $\mathrm{hr}$ & $\%$ & $3.00 \%$ & $11.10 \%$ & $39.10 \%$ & $3.40 \%$ & $18.70 \%$ & \\
\hline & & 3 & F & 1 & 0 & 28 & 1 & 30 & \\
\hline & & $\mathrm{hr}+$ & $\%$ & $1.50 \%$ & $0.00 \%$ & $21.90 \%$ & $1.10 \%$ & $9.70 \%$ & \\
\hline
\end{tabular}




\begin{tabular}{|c|c|c|c|c|c|c|c|c|c|}
\hline \multicolumn{2}{|c|}{$\begin{array}{l}\text { Corporate } \\
\text { communication media }\end{array}$} & & & \multicolumn{4}{|c|}{ District } & \multirow[t]{2}{*}{ Total } & \multirow[t]{2}{*}{$\begin{array}{c}\text { Test } \\
\text { statistics }\end{array}$} \\
\hline & & & & Bengaluru & Dharwad & Kalaburagi & Mysuru & & \\
\hline \multirow[t]{10}{*}{ Advertisement } & & \multirow[t]{2}{*}{ Yes } & $\mathrm{F}$ & 73 & 70 & 112 & 124 & 379 & $\mathrm{CV}=.327$ \\
\hline & & & $\%$ & $48.70 \%$ & $46.70 \%$ & $74.70 \%$ & $82.70 \%$ & $63.20 \%$ & $\mathrm{P}=.000$ \\
\hline & \multirow{8}{*}{$\begin{array}{l}\text { Time } \\
\text { spent }\end{array}$} & \multirow{2}{*}{$\begin{array}{l}<1 \\
\mathrm{hr}\end{array}$} & $\mathrm{F}$ & 54 & 36 & 34 & 99 & 223 & $\mathrm{CV}=.371$ \\
\hline & & & $\%$ & $74.00 \%$ & $51.40 \%$ & $30.40 \%$ & $79.80 \%$ & $58.80 \%$ & $\mathrm{P}=.000$ \\
\hline & & \multirow{2}{*}{$\begin{array}{l}1-2 \\
\mathrm{hr}\end{array}$} & $\mathrm{F}$ & 15 & 28 & 14 & 19 & 76 & \\
\hline & & & $\%$ & $20.50 \%$ & $40.00 \%$ & $12.50 \%$ & $15.30 \%$ & $20.10 \%$ & \\
\hline & & \multirow{2}{*}{$\begin{array}{l}2-3 \\
\mathrm{hr}\end{array}$} & $\mathrm{F}$ & 4 & 6 & 19 & 2 & 31 & \\
\hline & & & $\%$ & $5.50 \%$ & $8.60 \%$ & $17.00 \%$ & $1.60 \%$ & $8.20 \%$ & \\
\hline & & \multirow{2}{*}{$\begin{array}{l}3 \\
\mathrm{hr}+\end{array}$} & $\mathrm{F}$ & 0 & 0 & 45 & 4 & 49 & \\
\hline & & & $\%$ & $0.00 \%$ & $0.00 \%$ & $40.20 \%$ & $3.20 \%$ & $12.90 \%$ & \\
\hline \multirow{10}{*}{$\begin{array}{c}\text { Events and } \\
\text { exhibits }\end{array}$} & & \multirow[t]{2}{*}{ Yes } & $\mathrm{F}$ & 67 & 30 & 127 & 100 & 324 & $\mathrm{CV}=.486$ \\
\hline & & & $\%$ & $44.70 \%$ & $20.00 \%$ & $84.70 \%$ & $66.70 \%$ & $54.00 \%$ & $\mathrm{P}=.000$ \\
\hline & \multirow{8}{*}{$\begin{array}{l}\text { Time } \\
\text { spent }\end{array}$} & \multirow{2}{*}{$\begin{array}{l}<1 \\
\mathrm{hr}\end{array}$} & $\mathrm{F}$ & 47 & 25 & 31 & 75 & 178 & $\mathrm{CV}=.307$ \\
\hline & & & $\%$ & $70.10 \%$ & $83.30 \%$ & $24.40 \%$ & $75.00 \%$ & $54.90 \%$ & $\mathrm{P}=.000$ \\
\hline & & \multirow{2}{*}{$\begin{array}{l}1-2 \\
\mathrm{hr}\end{array}$} & $\mathrm{F}$ & 12 & 3 & 73 & 15 & 103 & \\
\hline & & & $\%$ & $17.90 \%$ & $10.00 \%$ & $57.50 \%$ & $15.00 \%$ & $31.80 \%$ & \\
\hline & & \multirow{2}{*}{$\begin{array}{l}2-3 \\
\mathrm{hr}\end{array}$} & $\mathrm{F}$ & 6 & 2 & 9 & 8 & 25 & \\
\hline & & & $\%$ & $9.00 \%$ & $6.70 \%$ & $7.10 \%$ & $8.00 \%$ & $7.70 \%$ & \\
\hline & & \multirow{2}{*}{$\begin{array}{l}3 \\
\mathrm{hr}+\end{array}$} & $\mathrm{F}$ & 2 & 0 & 14 & 2 & 18 & \\
\hline & & & $\%$ & $3.00 \%$ & $0.00 \%$ & $11.00 \%$ & $2.00 \%$ & $5.60 \%$ & \\
\hline \multirow{10}{*}{$\begin{array}{c}\text { Corporate } \\
\text { Information } \\
\text { on Social } \\
\text { media }\end{array}$} & & \multirow[t]{2}{*}{ Yes } & $\mathrm{F}$ & 87 & 88 & 134 & 105 & 414 & $\mathrm{CV}=.274$ \\
\hline & & & $\%$ & $58.00 \%$ & $58.70 \%$ & $89.30 \%$ & $70.00 \%$ & $69.00 \%$ & $\mathrm{P}=.000$ \\
\hline & \multirow{8}{*}{$\begin{array}{l}\text { Time } \\
\text { spent }\end{array}$} & \multirow{2}{*}{$\begin{array}{l}<1 \\
\mathrm{hr}\end{array}$} & $\mathrm{F}$ & 66 & 63 & 31 & 80 & 240 & $\mathrm{CV}=.335$ \\
\hline & & & $\%$ & $75.90 \%$ & $71.60 \%$ & $23.10 \%$ & $76.20 \%$ & $58.00 \%$ & $\mathrm{P}=.000$ \\
\hline & & \multirow{2}{*}{$\begin{array}{l}1-2 \\
\mathrm{hr}\end{array}$} & $\mathrm{F}$ & 13 & 12 & 19 & 13 & 57 & \\
\hline & & & $\%$ & $14.90 \%$ & $13.60 \%$ & $14.20 \%$ & $12.40 \%$ & $13.80 \%$ & \\
\hline & & \multirow{2}{*}{$\begin{array}{l}2-3 \\
\mathrm{hr}\end{array}$} & $\mathrm{F}$ & 5 & 12 & 33 & 8 & 58 & \\
\hline & & & $\%$ & $5.70 \%$ & $13.60 \%$ & $24.60 \%$ & $7.60 \%$ & $14.00 \%$ & \\
\hline & & \multirow{2}{*}{$\begin{array}{l}3 \\
\mathrm{hr}+\end{array}$} & $\mathrm{F}$ & 3 & 1 & 51 & 4 & 59 & \\
\hline & & & $\%$ & $3.40 \%$ & $1.10 \%$ & $38.10 \%$ & $3.80 \%$ & $14.30 \%$ & \\
\hline
\end{tabular}

About $54 \%$ of the respondents visited corporate events and exhibits. While analysing the time spent attending corporate events and exhibits it was found that $54.9 \%$ of the respondents spent less than 1 hour, $31.8 \%$ of them spent $1-2$ hours, $7.7 \%$ of them spent $2-3$ hours and remaining $5.6 \%$ of them spent more than 3 hours attending corporate events and exhibits. Also, it was found that $84.7 \%$ of the respondents from Kalaburagi spent more time attending corporate events and exhibits and in Dharwad, $20 \%$ of the respondents spent the least time attending corporate events and exhibits. (See Table 2)

Almost $69 \%$ of the respondents accessed corporate information on social media. While analysing the time spent on accessing corporate information on social media it was found that $58 \%$ of the respondents spent less than 1 hour, $13.8 \%$ of them spent $1-2$ hours, $14 \%$ of them spent 2-3 hours and remaining $14.3 \%$ of them spent more than 3 hours visiting corporate websites. Also, it was found that $89.3 \%$ of the respondents from Kalaburagi spent more time accessing 
corporate information on social media and in Bengaluru, 58\% of the respondents spent the least time accessing corporate information on social media. (See Table 2)

Among the various corporate communication media, the present study revealed that majority of the respondents i.e. $69 \%$ used corporate information from social media, followed by listening to oral media $(67.5 \%)$ and visiting the corporate website by $66.5 \%$. Corporate annual reports were the least accessed corporate communication media with only $51.7 \%$ of the respondents using it. Hence, it is obvious that with the advent and mass usage of social media across nations, 'corporate information from social media' is the most popular corporate communication media accessed by masses.

District wise analysis (average of percentages) of corporate communication media showed that $86.5 \%$ of the respondents from Kalaburagi are better exposed and used to corporate communications media in Karnataka, compared to other districts with Mysuru-66.19\%, Bengaluru $-50.49 \%$ and Dharwad $-43.53 \%$. This shows that corporate communication media is accessed largely in the rural areas too.

The study revealed that $92 \%$ of the respondents in Kalaburagi use internal media like house journals, printed literature etc, followed by oral media with $91.3 \%$ and corporate information on social media with $89.3 \%$. In Mysuru district corporate advertising $(82.7 \%)$, corporate website $(73.3 \%)$ and corporate information on social media $(70 \%)$ are the most popular corporate communication media used. In Bengaluru district, also corporate information on social media is ranked high with $58 \%$ of the respondents, followed by internal media (55.3\%) and oral media (52.7\%). In Dharwad district, oral media (78\%) and corporate information on social media $(58.7 \%)$ were more popular compared to other corporate communication media.

District wise comparison revealed a significant association $(\mathrm{CV}=.382 ; \mathrm{p}=.000)$ between the respondents of various districts listening to oral media. Cramer's V revealed a significant association $(\mathrm{CV}=.356 ; \mathrm{p}=.000)$ between time spent on listening to oral media and districts. The district wise comparison revealed a significant association $(\mathrm{CV}=.456 ; \mathrm{p}=.000)$ in respondents reading internal media like in-house journals. Cramer's V revealed a significant association $(\mathrm{CV}=.274 ; \mathrm{p}=.000)$ between time spent reading in-house journals, printed literature etc and districts. The district wise comparison revealed a significant association $(\mathrm{CV}=.211 ; \mathrm{p}=.000)$, between the respondents of various districts visiting corporate websites. Further, Cramer's V revealed a significant association $(\mathrm{CV}=.257 ; \mathrm{p}=.000)$ between time spent visiting corporate websites and districts. The district wise comparison revealed a significant association ( $\mathrm{CV}=.489$; $\mathrm{p}=.000$ ), between the respondents of various districts reading corporate annual reports. Further, Cramer's V revealed a significant association $(\mathrm{CV}=.355 ; \mathrm{p}=.000)$ between time spent and districts. The district wise comparison viewing corporate advertisements revealed a significant association $(\mathrm{CV}=.327 ; \mathrm{p}=.000)$, between the respondents of various districts viewing corporate advertisements. Further, Cramer's V revealed a significant association $(\mathrm{CV}=.371 ; \mathrm{p}=.000)$ between time spent visiting corporate advertisements and districts. The district wise comparison of respondents visiting corporate events and exhibits revealed a significant association ( $\mathrm{CV}=.486$; $\mathrm{p}=.000)$. Further, Cramer's V revealed a significant association $(\mathrm{CV}=.307 ; \mathrm{p}=.000)$ between time spent on visiting corporate events and exhibits and districts. The district-wise comparison revealed a significant association $(\mathrm{CV}=.274 ; \mathrm{p}=.000)$, between the respondents of various districts accessing corporate information on social media. Further, Cramer's V revealed a significant association $(\mathrm{CV}=.335 ; \mathrm{p}=.000)$ between time spent by respondents accessing 
corporate information on social media and districts. (See Table 2)

\subsection{Mass media exposure versus corporate communication media exposure}

The average of percentages of mass media stood at $86.7 \%$ compared to corporate communication media which showed only $61.5 \%$. This clearly indicates that the respondents from Bengaluru, Dharwad, Kalaburagi and Mysuru districts still prefer or spend more time accessing mass media like newspaper, radio, TV, Internet \& mobile phones compared to corporate communication media like oral media, internal media, corporate website, corporate annual reports, corporate advertising, corporate events \& exhibits, corporate information on social media. Hence, it is evident that mass media prevails over corporate communication media in Karnataka. Mass media is still the most accessed media by many, as it is easily accessible or available and the content is more generic $\&$ affects their daily lives.

\section{Major Findings}

The following are the major findings of the study:

1. Among the mass media, the newspaper was more prominent with $97 \%$ of the respondents reading it every day, followed by mobile with $93.5 \%$ and Internet with $92 \%$.

2. The least accessed media was the magazine with $70 \%$ of the respondents reading it.

3. Bengaluru and Mysuru districts have an edge in the newspaper readership, magazine readership, Television viewership, internet usage and also mobile usage.

4. Dharwad and Kalaburagi districts have better radio listenership.

5. District wise analysis (average of percentages) of mass media showed that $89.2 \%$ of the respondents from Mysuru district are better exposed and used mass media in Karnataka, compared to other districts with Kalaburagi $-87 \%$, Bengaluru $-86.8 \%$ and Dharwad $-83.9 \%$.

6. The following corporate communication media were used in Karnataka: Oral media, internal media, corporate websites, corporate annual reports, corporate advertising, corporate events and exhibits and corporate information on social media.

7. Among the various corporate communication media, the majority of the respondents i.e. $69 \%$ used corporate information from social media, followed by listening to oral media (67.5\%) and visiting the corporate website by $66.5 \%$.

8. Corporate annual reports were the least accessed corporate communication media with only $51.7 \%$ of the respondents using it.

9. District wise analysis (average of percentages) of corporate communication media showed that $86.5 \%$ of the respondents from Kalaburagi are better exposed and used to corporate communications media in Karnataka, compared to other districts with Mysuru - 66.19\%, Bengaluru $-50.49 \%$ and Dharwad $-43.53 \%$.

10. The average of percentages of mass media showed $86.7 \%$ compared to corporate communication media which showed only $61.5 \%$. Hence, Mass media prevails over corporate communication media in Karnataka.

\section{Conclusion}

The present study attempted to individually analyse mass media profiles and also make a comparative evaluation of corporate communication media. The survey results clearly show that 
mass media was still highly prevalent and used largely in comparison to corporate communication media by the people of Karnataka. Many people access mass media, as it is easily accessible or available and the content is more generic \& influences their daily lives.

The study found that among the various mass media, the newspaper was more prominent (97\%), followed by mobile with $93.5 \%$ and Internet with $92 \%$ of the respondents using it regularly. Hence, it can be inferred that in Karnataka, still print media especially, the newspaper is the most preferred and extensively used mass media, even in the rural districts.

The research study found the following types of corporate communication media used in Karnataka, namely: Oral media, internal media, printed literature, corporate websites, corporate annual reports, corporate advertisements, corporate events and exhibits, corporate information on social media. Among the various corporate communication media, corporate information from social media (69\%) was more prominent, followed by listening to oral media with $67.5 \%$ and visiting the corporate website by $66.5 \%$ of the respondents. Hence, it is obvious that with the advent and mass usage of social media across nations, 'corporate information from social media' is the most popular corporate communication media accessed by masses, even in Karnataka.

The district wise analysis (average of percentages) of mass media showed that Mysuru district (89.2\%) was better exposed to mass media in Karnataka, followed by Kalaburagi-87\%, Bengaluru $-86.8 \%$ and Dharwad $-83.9 \%$. This clearly indicates that tier-II cities are having better access to mass media compared to urban or cosmopolitan cities.

On the other hand, the district-wise analysis (average of percentages) of corporate communication media showed that Kalaburagi district (86.5\%) is better exposed and used to corporate communications media in Karnataka, followed by Mysuru-66.19\%, Bengaluru $50.49 \%$ and Dharwad $-43.53 \%$. This shows that corporate communication media is accessed largely in the rural areas too.

Overall, the mass media usage and corporate communication media usage clearly indicates that the heterogeneous audiences in Karnataka access all the possible channels for diverse information. The study shows the relevance of both mass media and corporate communication media in a socially diverse state of Karnataka. The research has also highlighted the emergence of corporate communication media as an easy alternative channel for corporate enterprises or organisations to disseminate information to their stakeholders in parallel to the mainstream mass media, even in tier-II cities or rural districts of Karnataka.

\section{Limitation and Future Research}

The present study has investigated media access and usage patterns of both mass media and corporate communication media in only 4 selected districts in Karnataka, namely, Bengaluru, Dharwad, Kalaburagi and Mysuru. Further, a comparative analysis was made to ascertain the above-mentioned findings. However, this research study also has its limitations of sample size, recall, and diversity of the respondents. Also, the findings cannot be generalised for the whole of India, as the sample size was limited to only 4 districts in Karnataka. Future research studies in media access and usage can be further explored with larger sample sizes across India or even across the world. Also, a study comparing traditional media or folk media with mass media and corporate communication media can be studied by adding a whole new dimension to the field of corporate communication. 


\section{References}

1. Argenti, Paul A. (2013) Corporate Communication, $6^{\text {th }}$ edition, McGraw Hill Education (India) Private Limited.

2. Balmer, J., \& Gray, E. (1999). Corporate Identity and Corporate Communications: Creating a Competitive Advantage. Corporate Communications: An International Journal, 4 (4), 171-177.

3. Capretz, L.F., Gidion, G., Grosch, M., \& Meadows, K.N. (2015). Media Usage Survey: Overall Comparison of Faculty and Students. CoRR, abs/1508.00043.

4. Fernandez, Joseph (2004) Corporate Communication - A $21^{\text {st }}$ Century Primer, Response Books, New Delhi.

5. G. Gideon, L.F. Capretz, G. Grosch and K. Meadows, "Media usage survey: how engineering instructors and students use media," Proceedings of Canadian Engineering Education Association (CEEA13) Conference, Montreal, pp. 1-5, June 2013.

6. Gentile, Douglas A., Walsh, David A. (1999) Media Quotient: National Survey of Family Media Habits, Knowledge, and Attitudes, Report by National Institute on Media and the Family, Minneapolis, MN.

7. Gray, E.R. \& Balmer, J.M.T. (1998) Managing Corporate Image and Corporate Reputation, Long Range Planning, 31 (5), 695-702.

8. Guru, Mahesh Chandra B.P and Raghavendra, R. (2013) Corporate Communication in Public and Private Corporate Houses of Karnataka State: An Empirical Study, International Journal of Entrepreneurship \& Business Environment Perspectives, Vol 2., No. 4.

9. Heim J. and Brandtzaeg, P.B. (2007) Patterns of Media Usage and the Non-professional Users. Paper presented at the workshop: "Supporting non-professional users in the new media landscape", CHI 2007, April 28 - May 3, 2007, San Jose, USA

10. Jackson P. (1987) Corporate Communication for managers, Pitman London.

11. Jethwaney, Jaishri (2013) Corporate Communication, $3^{\text {rd }}$ edition, Oxford University Press.

12. Jethwaney, Jaishri \& Sarkar N.N. (2009) Public Relations Management, Sterling Publishers Pvt Ltd.

13. Mahalanobis, Parvati (2005) Public Relations \& Corporate Communications, $1^{\text {st }}$ edition, Dominant Publishers and Distributors.

14. Riel, Cees B.M. van and Fombrum, Charles J. (2007) Essentials of Corporate Communication, Routledge.

15. Riel, Van C. B. M. (1995) Principles of Corporate Communication, Pearson

16. Financial Times, New York.

17. Sommerlad, Lloyd E. (1966) The Press in Developing Countries, Sydney University Press.

18. Schramm, Wilbur. (1964) Mass Media and National Development: The Role of Information in the Developing countries, Stanford University Press.

19. Trivedi, Megha. (2014) Competitive Advantage through Corporate Communication, unpublished thesis, Nirma University, India.

20. Vahlberg, V. (2010) Fitting into their Lives, A Survey of Three Studies About Youth Media Usage, Newspaper Association of America Foundation.

21. Wright, C. R. (1988). Social surveys and the use of the mass media: The case of the aged. In H. J. O'Gorman (Ed.), Surveying social life: Papers in honour of Herbert H. Hyman (pp. 467-486). Middletown, Conn.: Wesleyan University Press. 